\title{
Tin-based opacifiers in archaeological glass and ceramic glazes: a review and new perspectives
}

\author{
Moujan Matin ${ }^{1,2}$ \\ Received: 3 August 2018 / Accepted: 9 October 2018 / Published online: 12 November 2018 \\ (C) The Author(s) 2018
}

\begin{abstract}
Tin-based opacification by tin oxide and lead-tin-oxide particles was used in glass production since the first millennium BC and in ceramic glazes since the eighth century AD. Opacification process is often characterised by significant amounts of tin oxide and lead oxide dispersed into glassy matrices or by identification of the opacifying particles by means of microstructural or (micro-)XRD analyses. The processes of opacification and manufacture are usually more difficult to establish from compositional and microstructural analyses because they leave little diagnostic traces. This review aims to integrate compositional data on archaeological glass and glazes and in particular the $\mathrm{Pb} / \mathrm{Sn}$ values, with descriptions of the opacification processes in historical treatises, observations at traditional workshops, and the results of previous replication experiments to shed further light on technological issues underlying these methods of opacification and highlight new research perspectives.
\end{abstract}

Keywords Tin-based opacification · Glass · Ceramic glazes · Compositional data · Production processes · Archaeology and anthropology of technology

\section{Introduction}

Tin-based opacifiers and colourants, namely lead-tin-oxide and tin oxide, were used to produce, respectively, yellow and white glass and glazes. They were also used as opacifiers in glass and glazes coloured by other metallic oxides, such as oxides of copper, manganese, and cobalt. In ceramic glazes, the technique marked a turning point in the development of West Asian and European ceramics (e.g. Caiger-Smith 1973). The opacified glazes applied over the entire surface disguised the ceramics bodies and provided a smooth background onto which decorations could be applied.

Electronic supplementary material The online version of this article (https://doi.org/10.1007/s12520-018-0735-2) contains supplementary material, which is available to authorized users.

Moujan Matin

moujan.matin@wolfson.ox.ac.uk

1 Wolfson College, University of Oxford, Linton Road, Oxford OX2 6UD, UK

2 Research Laboratory for Archaeology and the History of Art, University of Oxford, Dyson Perrins Building, South Parks Road, Oxford OX1 3QY, UK
The use of tin-based opacifiers was preceded by that of antimony-based opacifiers (i.e. lead-antimony-oxide yellow and calcium-antimony-oxide white), which were first used in Egypt and the Near East in the production of opaque glasses in the mid second millennium BC and then continued in use until about the fourth century AD (Turner and Rooksby 1961, 3-5). For a short period during the first to second centuries BC, lead-tin-oxide yellow glass was produced in northwestern Europe (Werner and Bimson 1967; Henderson and Warren 1983), while evidence of tin oxide white glass in this period is rare. Lead-tin-oxide yellow glass resumed production from the first to third centuries AD in Britain (Henderson and Warren 1983; Biek and Kay 1982; Rooksby 1962) and from about the fourth century AD in western Europe (e.g. Aquileia, Italy, Maltoni and Silvestri 2018; Bayley 1981). During the Late Antique period (fifth to seventh centuries AD), lead-tinoxide yellow glass was produced and used as a dominant type of glass at Wijnaldum (Henderson 1999) and Maastricht (Sablerrolles et al. 1997) in the Netherlands, at Eriswell (Peake and Freestone 2014) and Apple Down Cemetery (Henderson 1990) in England, at Dunmisk Fort in Ireland (Henderson 1988), at Tarbat Ness in Scotland (Peake and Freestone 2014), and at Naples (Schibille et al. 2018a), Ravenna (Vandini et al. 2014), Padua (Silvestri et al. 2014), 
and Milan (Neri et al. 2013, 3-4) in Italy. Concurrently, tin oxide was used in glass but appears to have been far less popular than lead-tin-oxide glass and was initially used as an opacifier in glasses coloured by other colourants. Among the earliest published examples are the purple-brown tesserae from a Roman tower at Centcelles, near Tarragona, Spain, dated to 330-350 AD, which was opacified by tin oxide particles and coloured by oxides of chromium, iron, and manganese (Turner and Rooksby 1961, 3; Rooksby 1962). Tin oxide opacification continued through early medieval Europe in white glasses, including in England (Bayley and Wilthew 1986; Henderson 1990; Bayley 2000), Ireland (Henderson 1988), the Netherlands (Sablerrolles et al. 1997), and Italy (Uboldi and Verità 2003; Arletti et al. 2011a, b; Neri et al. 2013, 3-4), and in blue glasses in Denmark (Henderson and Warren 1983).

In the Eastern Mediterranean and the Levant, lead-tinoxide opaque glass was used from the fourth century in yellow glasses, as well as in green glasses coloured by copper oxide $(\mathrm{CuO})$, and in red glasses coloured by cuprite $\left(\mathrm{Cu}_{2} \mathrm{O}\right)$. Examples of such glasses were found in opus sectile panels in Greece (Brill and Whitehouse 1988; Brill 1999, sections VH, VI, VJ), at Shikmona in Israel (fifth c., Freestone et al. 1990), at Kilise Tepe (fifth to sixth c., Neri et al. 2017), Hagios Polyeuktos (sixth c., Schibille and McKenzie 2014), and Sagalasses in Turkey (sixth c., Schibille et al. 2012), at Petra in Jordan (fifth to seventh c., Marii 2013), and in Cyprus (fifth to seventh c., Bonnerot et al. 2016). During the early Islamic period, the use of lead-tin-oxide glass continued as attested in a set of glass tesserae found at Khirbet al-Mafjar in Jericho, Palestine (eighth c., Fiorentino et al. 2017, 2018), and Qusayr' Amra, Jordan (eighth c., Verità et al. 2017), as well as eastwards in Samarra (ninth c., Schibille et al. 2018b; M. Wypyski 2015, pers. comm.) and Ctesiphon, Iraq (9th c., Schibille et al. 2018b), Amorium, Turkey (ninth c., Wypyski 2005), and Nishapur, Iran (eighth to tenth c., Pilosi et al. 2012; Wypyski 2015). Tin oxide seems to have been more popular as an opacifier for blue and red glasses during the Late Antique in Israel (Freestone et al. 1990), Cyprus (Bonnerot et al. 2016) and Turkey (Schibille and McKenzie 2014, Wypyski 2005). It was only later in the Islamic period during the ninth to tenth centuries in Iraq and Iran that tin oxide was more commonly used as white colourant in glass (Schibille et al. 2018b, M. Wypyski 2015, pers. comm.).

The use of lead-tin-oxide and tin oxide opacifiers in ceramic glazes began in Egypt and the Levant about the eighth century during the early Islamic period (Matin et al. 2018; Tite et al. 2015). The earliest examples are ceramics painted with lead-tin-oxide yellow glaze in discrete bands, found in several Umayyad-period sites, such as Fustat (Scanlon 1998; Gayraud 2009), Abu Mina (Engeman 1990), and Tod (Joel 1992) in Egypt; Aqaba (Whitcomb 1989, 1991, 48-56) and
Pella (Walmsley 1995, 664 and; 667; Walmsley 1997, 2-3) in Jordan; and Tiberias (Stacey 1995,164-166, 286), Yoqne'am (Avissar 1996), and Caesarea (Arnon 2008, 35 and 400) in Israel. This technique was later developed to cover the overall surface of ceramics by lead-tin-oxide yellow or tin oxide white glazes, examples being excavated in Tell Aswad (Watson 1999), Al-Mina (Vorderstrasse 2005, 75-78), and Qinnasrin (Whitcomb 1999, 81-83) in Syria and Antioch (Waage 1948) and Tarsus (Bagci 2016) in Turkey. From around the ninth century, lead-tin oxide yellow and tin oxide white glazes were used in Abbasid Mesopotamia, with the latter gaining more popularity due to its resemblance to the white surface of Chinese Tang stoneware and porcelain (Wood et al. 2007; Mason and Tite 1997; Molina et al. 2014; Matin et al. 2018). Subsequently, tin oxide white glazes spread throughout the Islamic world and became the mainstream glazing technique used on medieval Islamic pottery, including lustre wares from Iran, Syria, Egypt, and Spain (Mason and Tite 1997; Pradell et al. 2008), Mina' $i$ wares from Iran (Mason et al. 2001), and Iznik wares from Turkey (Henderson 1989; Tite 1989; Paynter et al. 2004; Okyar 2002; Tite et al. 2016). In Spain and Italy, tin oxide white glazes gave rise to the production of maiolica wares from thirteenth to seventeenth century AD (Molera et al. 2001; Tite 2009) and continued in the Netherlands, Germany, Eastern Europe, and Britain (CaigerSmith 1973, 127-140; Fourest 1980). Lead-tin-oxide yellow glazes, on the other hand, seem to have spread more strongly eastwards to Northern and Eastern Iran and Central Asia during the tenth to thirteenth centuries $\mathrm{AD}$, where examples of tin oxide white glazes are scant, but still existing (Matin et al. 2018, Appendix). Finally, lead-tin oxide yellow glazes were used in tile decorations from around the sixteenth century to nineteenth century in India (Gill et al. 2014) and for, so-called, haft-rang (seven-colour) tiles in Iran (Isfahani 1888; Holakooei et al. 2014; Matin and Nemati forthcoming).

The increasing amount of data published over the recent years on lead-tin-oxide and tin oxide glasses and glazes has provided an opportunity to understand and identify different trends of production. The lack of information on the methods and mechanisms associated with the production of these glasses and glazes has been largely filled with recently published replication experiments, supported by historical texts. The aim of this review is to integrate published analytical data on glasses and glazes with a better understanding of the different ways in which they were produced. In doing so, it will be taken as a starting point the explanations of the processes of preparing lead-tin calx, anima, and alkali frit. It will, then, be discussed how these products can be detected by means of scientific analyses of glasses and glazes, with support for these hypotheses being provided by evidence from primary texts and observations at traditional workshops. 
"Calx," "lead-tin anima," and "lead-tin alkali frit": insights into the methods of production

\section{Lead-tin calx}

Calx is the fine powder that is left after a metal or a mixture of metals has been calcined (oxidised) by heating in air to temperatures above the melting point. Producing lead-tin calx involves heating a mixture of lead and tin to their melting point and beyond to temperatures above $600{ }^{\circ} \mathrm{C}$, while occasionally stirring the mixture. The resulting calx powder varies in colour from whitish yellow, when lead content is negligible, to deep yellow, when it contains lead in considerable amounts. The calcination reaction, as outlined below, is controlled by the composition of the mixture.

$$
\begin{aligned}
& \mathrm{Pb}+\mathrm{O}_{2} \rightarrow 2 \mathrm{PbO} \\
& \mathrm{Sn}+\mathrm{O}_{2} \rightarrow \mathrm{SnO}_{2} \\
& \mathrm{SnO}_{2}+2 \mathrm{PbO} \rightarrow \mathrm{Pb}_{2} \mathrm{SnO}_{4}
\end{aligned}
$$

\section{$\mathrm{Pb} / \mathrm{Sn}$ less than 3.5}

If the $\mathrm{Pb} / \mathrm{Sn}$ ratio is less than the stoichiometric requirement of 3.5 for the formation of $\mathrm{Pb}_{2} \mathrm{SnO}_{4}$ in the reaction (c), only the calcining reactions (a) and (b) occur and the resulting calx would contain a mixture of $\mathrm{PbO}$ and $\mathrm{SnO}_{2}$, in addition to some unreacted $\mathrm{SnO}, \mathrm{Pb}$, and $\mathrm{Sn}$. This type of lead-tin calx was used as a white colourant and opacifier in archaeological glass and glazes (Matin et al. 2018). The calx could have been mixed with either only silica, a mixture of silica and alkalis, or a preprepared glassy frit, and subsequently fired to produce a glass or glaze opacified by $\mathrm{SnO}_{2}$ particles (Fig. 1, path 1).

\section{$\mathrm{Pb} / \mathrm{Sn}$ greater than 3.5}

If $\mathrm{Pb} / \mathrm{Sn}$ ratio is sufficient or more than the stoichiometric requirement of 3.5 , the reactions (a), (b), and (c) are completed and the resulting calx powder would contain a combination of $\mathrm{PbO}, \mathrm{SnO}_{2}$, and $\mathrm{Pb}_{2} \mathrm{SnO}_{4}$, in addition to some unreacted $\mathrm{SnO}$, $\mathrm{Pb}$, and $\mathrm{Sn}$ (Fig. 1). Previous XRD analysis of replicated leadtin calces with $\mathrm{Pb} / \mathrm{Sn}$ ratios of 7 and 30 fired to $600{ }^{\circ} \mathrm{C}$ and $800{ }^{\circ} \mathrm{C}$ confirmed that the calx mixture contained lead-tinoxide type $\mathrm{I}\left(\mathrm{Pb}_{2} \mathrm{SnO}_{4}\right)$, cassiterite $\left(\mathrm{SnO}_{2}\right)$, massicot $(\mathrm{PbO}$, orthotombic structure), and litharge ( $\mathrm{PbO}$, tetragonal structure) (Matin et al. 2018). The subsequent treatment of the calx depended upon the concentrations of alkalis in the final glass or glaze product. On this basis, the calx which contained $\mathrm{Pb}_{2} \mathrm{SnO}_{4}$ would have been subsequently treated in two different ways, namely lead-tin anima and lead-tin alkali frit (Fig. 1, paths 2-4).

\section{Lead-tin anima}

In the absence or negligible amounts of alkalis (less than about $2 \mathrm{wt} \%)$, the calx was mixed with silica $\left(\mathrm{SiO}_{2}\right)$ and heated to above approximately $800{ }^{\circ} \mathrm{C}$ to directly produce lead-tin-oxide yellow colourant and opacifier (Fig. 1, path 2). The resulting vitreous pigment is usually referred to as "anima" (plural anime), a term taken from Moretti and Hreglich (1984). During firing, variable amounts of $\mathrm{SiO}_{2}$ substituted for $\mathrm{SnO}_{2}$ in $\mathrm{PbSn}_{2} \mathrm{O}_{4}$ (type I) which caused a crystalline conversion to $\mathrm{Pb}(\mathrm{Sn}, \mathrm{Si}) \mathrm{O}_{3}$ (type II) structures (Rooksby 1964; Kühn 1968; Clark et al. 1995; Matin et al. 2018). On this basis, anima is typically identified in archaeological glass and ceramic glazes by two different analytical methods. First, XRD or micro-XRD can be used to identify $\mathrm{Pb}(\mathrm{Sn}, \mathrm{Si}) \mathrm{O}_{3}$ crystals, rather than the $\mathrm{PbSn}_{2} \mathrm{O}_{4}$ crystals present in the calx; and second, SEM-EDS or EPMA-WDS spot analysis can be used to show that the $\mathrm{Pb} / \mathrm{Sn}$ atomic ratios is $1: 1$, as associated with $\mathrm{Pb}(\mathrm{Sn}, \mathrm{Si}) \mathrm{O}_{3}$ crystals, rather than 1:2, as associated with the $\mathrm{PbSn}_{2} \mathrm{O}_{4}$ crystals of the calx. Lead-tin anime in compositions with negligible alkali contents were mainly used to produce yellow ceramic glazes.

In the presence of alkali salts, a different set of reactions occur. Previous experiments demonstrated that during firing of a mixture of a calx, which contained $\mathrm{Pb}_{2} \mathrm{SnO}_{4}$ with silica and alkalis, $\mathrm{Pb}(\mathrm{Sn}, \mathrm{Si}) \mathrm{O}_{3}$ crystals decomposed and secondary $\mathrm{SnO}_{2}$ crystals precipitated from the melt, and as a result, the colour of the glass or glaze changed from yellow to white (Matin et al. 2018). Without the addition of alkalis, the dissolution of $\mathrm{Pb}(\mathrm{Sn}, \mathrm{Si}) \mathrm{O}_{3}$ and the consequent precipitation of $\mathrm{SnO}_{2}$ would still occur but only at higher temperatures (Molera et al. 1999; Tite et al. 2008). In order to prevent this dissolution to happen in alkali-rich compositions, the $\mathrm{PbSn}_{2} \mathrm{O}_{4}$-containig calx was first mixed and heated with silica. The anima was then mixed with either pre-prepared alkali glass or alternatively with silica and alkalis and subsequently fired to produce yellow glasses or glazes on tiles (Fig. 1, path 3).

\section{Lead-tin alkali frit}

Direct mixing of $\mathrm{Pb}_{2} \mathrm{SnO}_{4}$-containing calx $(\mathrm{Pb} / \mathrm{Sn}>3.5)$ with silica and alkalis and firing the mixture to temperatures above approximately $750{ }^{\circ} \mathrm{C}$ - depending upon the exact composition of the mixture - resulted in the dissolution of the lead-tinoxide and consequent precipitation of tin oxide particles and as a result, a white opaque alkali frit would form (Fig. 1, path 4). The main application of this method was in opaque white pottery glazes as early as the eighth century AD in Egypt and the Levant (Matin et al. 2018), which continued as a primary glazing method in the Middle East, Central Asia, and Europe until the nineteenth century (see e.g. Isfahani 1888). For opaque white glasses, calces with $\mathrm{Pb} / \mathrm{Sn}$ less than 3.5 were mainly incorporated (Fig. 1, path 1) and the lead-tin alkali frit 
Fig. 1 Flowchart showing processes for producing glasses and glazes opacified by tin oxide (paths (1) and (4)) and lead-tinoxide (paths (2) and (3))

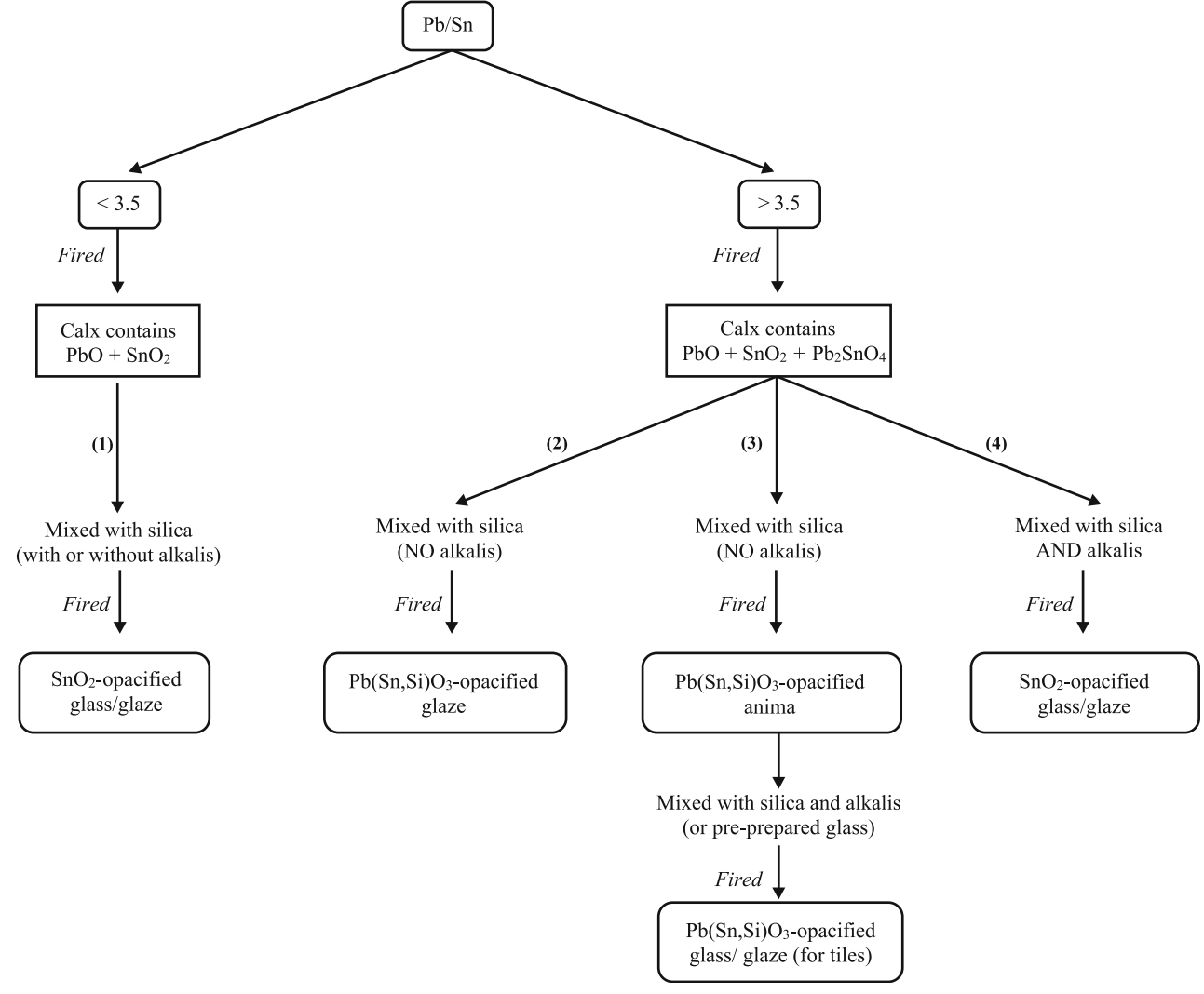

method seems not to have been commonly used except in few instances. It is likely that these samples might not in fact be related to a deliberate application of alkali frit but rather to the anime used in the glasses, which had accidentally reacted with the alkalis during firing and resulted in a glass opacified by tin oxide, rather than lead-tin-oxide.

\section{Glass opacified by lead-tin-oxide and tin oxide}

\section{Archaeological glass data}

Published data on the chemical composition of 82 yellow, 80 green, 45 red, 14 blue, and 32 white opaque glass samples spanning the period of second century BC to eleventh century $\mathrm{AD}$ is compiled in supplementary file Table S1. Figure 2 is a box and whisker plot of these data showing the distribution of $\mathrm{Pb} / \mathrm{Sn}$ values for each glass colour. Each box indicates lower quartile (25th percentile), median, and upper quartile (75th percentile). The whiskers represent data within 1.5 times the inter-quartile range. Outlier points lying beyond the whiskers are shown as individual points. Since the dataset is not normally distributed, it is more significant to use median than average to designate the central tendency of $\mathrm{Pb} / \mathrm{Sn}$ ratios.

$\mathrm{Pb} / \mathrm{Sn}$ median values of 1.3 and 0.6 for opaque blue and white glasses, respectively, (Fig. 2) indicate that they must have been opacified using calces with $\mathrm{Pb} / \mathrm{Sn}$ less than 3.5 , mainly containing $\mathrm{PbO}$ and $\mathrm{SnO}_{2}$ (see, Fig. 1, path 1). This assumption is confirmed by the fact that $\mathrm{SnO}_{2}$ crystals were identified by SEM-EDS or Raman spectroscopy measurements in blue glasses from Shikmona (Freestone et al. 1990), in white glasses from San Giovanni alle Fonti, Milan (Neri et al. 2013), and in blue and white glasses from Cyprus (Bonnerot et al. 2016). The amount of $\mathrm{Na}_{2} \mathrm{O}+\mathrm{K}_{2} \mathrm{O}$ is typically between 13.6 and $22.1 \mathrm{wt} \%$ for blue glasses and between 14.5 and $22.4 \mathrm{wt} \%$ for white glasses. Two exceptions were a white glass from Cyprus, dated to fifth to seventh century AD with $\mathrm{Pb} / \mathrm{Sn}$ of 5.2 and $\mathrm{Na}_{2} \mathrm{O}+\mathrm{K}_{2} \mathrm{O}$ of $6.3 \mathrm{wt} \%$ (Bonnerot et al. 2016), and a bluish white glass dated to sixth to ninth century $\mathrm{AD}$ with $\mathrm{Pb} / \mathrm{Sn}$ of 6.1 and $\mathrm{Na}_{2} \mathrm{O}+\mathrm{K}_{2} \mathrm{O}$ of 13.4 wt\% (Henderson 1999). The production of these two glasses might be associated with deliberate use of an alkali frit or with the use of an anima that had accidentally reacted with alkalis during firing. In either case, lead-tin-oxide crystals from the initial calx had dissolved in the glasses and tin oxide particles had precipitated as secondary crystals (see, Fig. 1, path 4).

For opaque yellow and green glasses, the median for the $\mathrm{Pb} /$ Sn values is 9.1 and 9.0, respectively, indicating that, unlike the blue and white glasses, they must have been opacified using calces with $\mathrm{Pb} / \mathrm{Sn}$ greater than 3.5 which mainly contained $\mathrm{PbO}, \mathrm{SnO}_{2}$ and $\mathrm{Pb}_{2} \mathrm{SnO}_{4}$ (see, Fig. 1). The significant concentrations of alkalis in yellow (2.2-20.6-wt\% $\mathrm{Na}_{2} \mathrm{O}+\mathrm{K}_{2} \mathrm{O}$ ) and green glasses (7.5-29.8-wt $\% \mathrm{Na}_{2} \mathrm{O}+\mathrm{K}_{2} \mathrm{O}$ ) 
Fig. 2 Box and whisker plot showing the distribution of $\mathrm{Pb} / \mathrm{Sn}$ values for glass samples opacified by lead-tin oxide and tin oxide. The solid bar indicates $\mathrm{Pb} / \mathrm{Sn}$ equal to 3.5

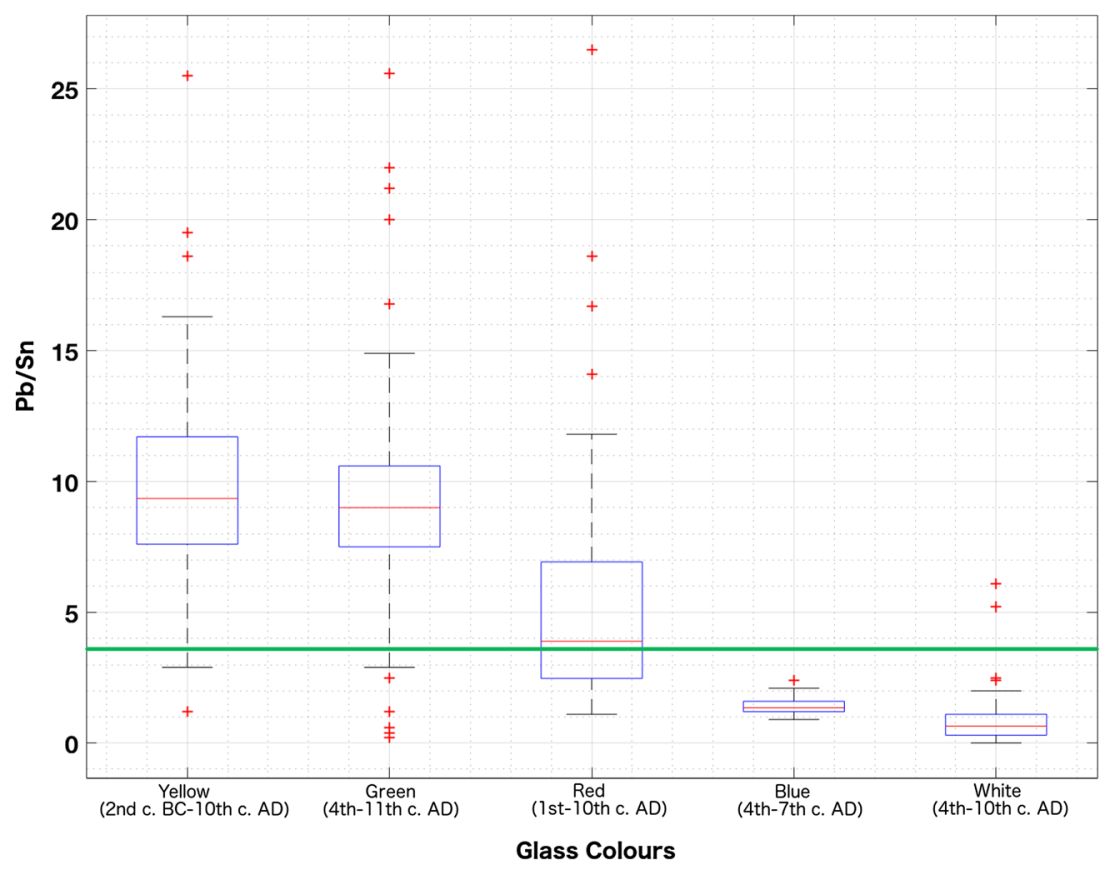

suggest that the calx powder must have been initially fritted with silica to produce anime with $\mathrm{Pb}(\mathrm{Sn}, \mathrm{Si}) \mathrm{O}_{3}$ crystals. The anime were subsequently mixed with pre-prepared alkali glass to produce yellow and green glasses (Fig. 2, path 3). The duration of heating would have been kept to a minimum to avoid dissolution of lead-tin-oxide crystals and hence the anime-based yellow glasses typically have relatively heterogenous microstructures. Characteristic features of this process as seen in SEM images are stratified glass microstructures with stripes containing $\mathrm{Pb}(\mathrm{Sn}, \mathrm{Si}) \mathrm{O}_{3}$ particles due to the addition of the anime. Examples are green glass tesserae from Kilise Tepe (Neri et al. 2017, Fig. 10e; sample KT NS 001, Pb/Sn=7.7) and Shikmona (Freestone et al. 1990, Fig. 3; sample 29353Q, $\mathrm{Pb} / \mathrm{Sn}=10.5)$ ). Alternatively, the microstructure of the glass might show bigger aggregates of lead-tin-oxide crystals within the glass matrix, such as in opaque yellow glass from Tarbat Ness, Scotland (Peake and Freestone 2014-Fig. 3.1-3.2, sample 25/1458, $\mathrm{Pb} / \mathrm{Sn}=8.4)$. In other cases, $\mathrm{Pb}(\mathrm{Sn}, \mathrm{Si}) \mathrm{O}_{3}$ crystals have been found more evenly dispersed in the glass. Such crystals were identified in yellow and green glasses from Hagios Polyeuktos (Schibille and McKenzie 2014), Shikmona (Freestone et al. 1990), Kilise Tepe (Neri et al. 2017), San Giovanni alle Fonti (Neri et al. 2013), Schleitheim (Heck et al. 2003), Cyrpus (Bonnerot et al. 2016), Khirbet alMafjar (Fiorentino et al. 2017), and Amorium (Wypyski 2005) by means of SEM-EDS, EPMA-WDS, Raman spectroscopy/microscopy or LA-ICP-MS.

A group of anise-green coloured tesserae from San Giovanni alle Fonti (Neri et al. 2013; samples Ve1-3, 5) with $\mathrm{Pb} / \mathrm{Sn}$ in the range $0.4-1.2$ were revealed to have been opacified by $\mathrm{SnO}_{2}$ and hence fall into the white and blue glass category discussed above (Fig. 1, path 1). One sample of anise green tesserae (Ve4) was found to contain significantly higher $\mathrm{Pb} / \mathrm{Sn}$ value of 6.5 and opacified by $\mathrm{SnO}_{2}$. It is likely that this sample was initially opacified using the $\mathrm{Pb}(\mathrm{Sn}, \mathrm{Si}) \mathrm{O}_{3}$ anime method (Fig. 1, path 3) but was accidentally fired for too long. During firing, $\mathrm{Pb}(\mathrm{Sn}, \mathrm{Si}) \mathrm{O}_{3}$ crystals would have reacted with alkalis and dissolved in the glass and $\mathrm{SnO}_{2}$ particles subsequently precipitated (Fig. 1, path 4).

Compositional data for opaque red glasses indicates that calces with a diverse range of $\mathrm{Pb} / \mathrm{Sn}$ ratio values between 1.1 and 26.5 and with a median of 3.9 were used for opacification. This suggests that both methods of opacification by $\mathrm{SnO}_{2}$ particles using calces with $\mathrm{Pb} / \mathrm{Sn}$ values less than 3.5 (Fig. 1, path 1) and by $\mathrm{Pb}(\mathrm{Sn}, \mathrm{Si}) \mathrm{O}_{3}$ particles in anima using calces with $\mathrm{Pb} / \mathrm{Sn}$ values greater than 3.5 were used in red glasses.

For samples of red glass from Amorium which were found to have been opacified by $\mathrm{SnO}_{2}$ particles (Wypyski 2005; samples $35-41$ ), the $\mathrm{Pb} / \mathrm{Sn}$ value for only one sample (no. 38) is less than 3.5 and the rest fall into the category of $\mathrm{Pb} / \mathrm{Sn}$ greater than 3.5. It is likely that, similar to the anise green sample Ve4 discussed above, the opacification process for the Amorium red glasses with $\mathrm{Pb} / \mathrm{Sn}$ values greater than 3.5 was a result of accidental reaction of $\mathrm{Pb}(\mathrm{Sn}, \mathrm{Si}) \mathrm{O}_{3}$ with alkalis and thus subsequent formation of secondary $\mathrm{SnO}_{2}$ crystals. Some discrepancies are also observed in the published data for red glasses. For instance, microstructural analysis of samples of red glass from Kilise Tepe indicated that they were opacified by $\mathrm{Pb}(\mathrm{Sn}, \mathrm{Si}) \mathrm{O}_{3}$ crystals dispersed in striped structures and with $\mathrm{Na}_{2} \mathrm{O}+\mathrm{K}_{2} \mathrm{O}$ ranging between 12.4 and 21 wt $\%$ (Neri et al. 2017; samples KT NS 003, 007, 019). This observation would immediately recall the lead-tin anime method of opacification as presented in Fig. 1, path 3 . However, the $\mathrm{Pb} / \mathrm{Sn}$ ratio values were reported to range between 1.7 and 2.2, which is notably 


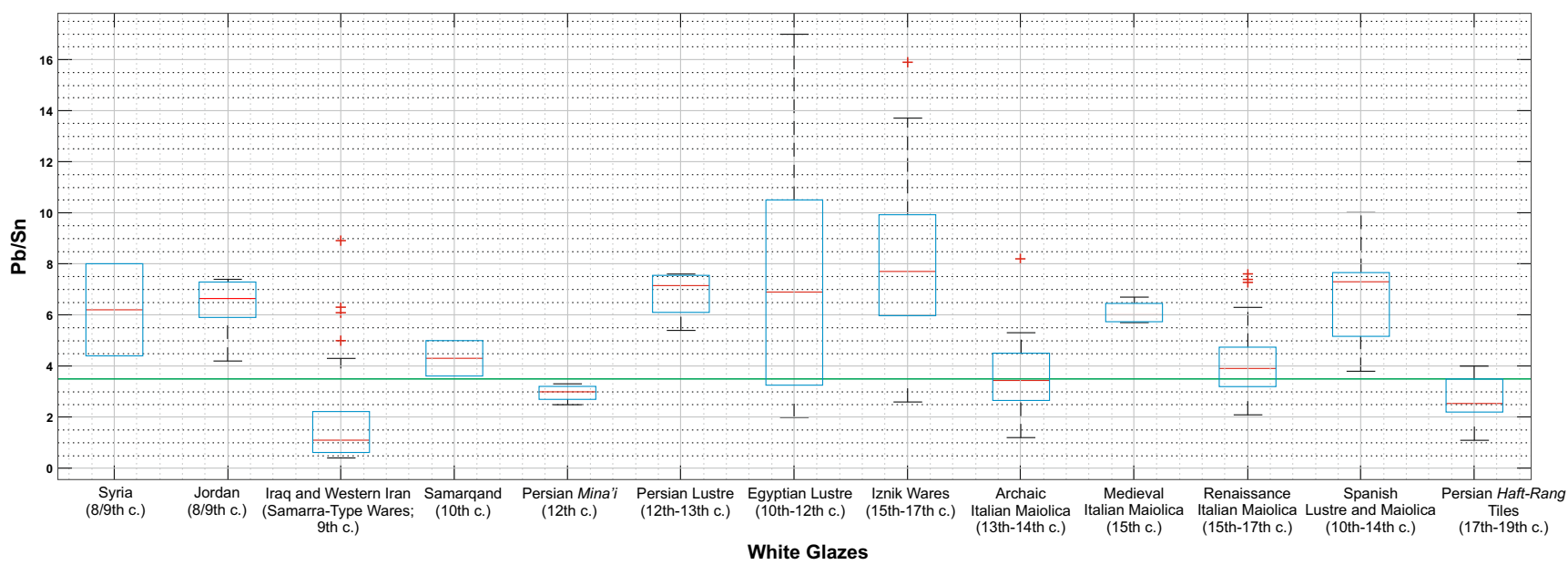

Fig. 3 Box and whisker plot showing the distribution of $\mathrm{Pb} / \mathrm{Sn}$ values for opaque white glazes. The solid bar indicates $\mathrm{Pb} / \mathrm{Sn}$ equal to 3.5

less than the minimum amount of 3.5 required for the $\mathrm{Pb}_{2} \mathrm{SnO}_{4}$ crystals to form in the calx. This might be due to analytical error in the determination of lead and tin in these samples. It would be useful to repeat the analysis for these samples.

\section{Archaeological glassmaking wastes}

A number of crucible fragments associated with the manufacture of lead-tin-oxide yellow glasses were found in a first- to third-century AD context in England (Catsgore, Somerset: Biek and Kay 1982) and in fifth- to seventh-century AD contexts in the Netherlands (Maastricht: Sablerrolles et al. 1997; Wijnaldum: Henderson 1999; Sablerrolles 1999; Rijnsburg: Bloemers et al. 1986), Switzerland (Schleitheim: Heck et al. 2003), and Ireland (Dunmisk Fort: Henderson 1988). Analyses of the glass attached to the crucible walls revealed a dispersion of lead-tin-oxide particles in a primarily silica glass (Biek and Kay 1982; Henderson 1988, 1999; Heck et al. 2003) and in the case of the Irish crucible glass, with some areas of pure silica (Henderson 1988). This evidence suggests that the crucibles were used in the process of firing a mixture of lead-tin-oxide calx powder and silica to produce lead-tin anime frit. The anime charge of the crucible was subsequently mixed and fired with a soda-lime glass to produce opaque yellow glass.

Table 1 shows the EDS chemical composition of crucible glass from Schleitheim (Heck et al. 2003) and Wijnaldum (Henderson 1999). For the Schleitheim samples, the $\mathrm{Pb} / \mathrm{Sn}$ value in the anime adhered to the crucible is directly comparable to that of glass bead, but the latter contains higher amounts of $\mathrm{SiO}_{2}, \mathrm{Na}_{2} \mathrm{O}$, and $\mathrm{CaO}$ indicating that glass with a soda-lime composition was added to the anime. Glass beads from Wijnaldum contain variable amounts of $\mathrm{Pb} / \mathrm{Sn}$, which are greater or less than that of the crucible glass. This suggests that either calces with a variety of $\mathrm{Pb} / \mathrm{Sn}$ ratios were used at the workshop or that some of the glass beads were imported to the site. As in the case of the Schleitheim samples, the amounts of $\mathrm{SiO}_{2}$, $\mathrm{Na}_{2} \mathrm{O}$, and $\mathrm{CaO}$ in glass beads from Wijnaldum are consistently higher than those in the crucible glass, which suggests that glass with soda-lime composition was added to the crucible anime.

\section{Glaze opacified by lead-tin-oxide and tin oxide}

\section{White glaze data}

Data on the chemical composition of 157 samples of white glazed ceramics spanning the period between the eighth and nineteenth centuries AD is compiled in Supplementary file Table $\mathrm{S} 2$, and the distribution of $\mathrm{Pb} / \mathrm{Sn}$ values is presented in Fig. 3. The majority of white glazes fall into the category with $\mathrm{Pb} / \mathrm{Sn}$ values greater than 3.5 and with the amount of alkalis varying between 1.8 and $13.3 \mathrm{wt} \%$, corresponding to the procedure shown in Fig. 1, path 4. This group includes early Islamic ceramics from the Levant and Central Asia (Samarqand); medieval lustre wares from Iran, Egypt, and Spain; Iznik wares; and maiolica wares from Spain and Italy (Fig. 3). The remainder correspond to the category with $\mathrm{Pb} / \mathrm{Sn}$ values less than 3.5 (Fig. 1, path 1) and include early Islamic white glazed wares from Iraq and western Iran (Abbasid Samarra-type blue-onwhite and lustre wares), Persian Mina' $i$ wares, haft-rang tiles, and the majority of Archaic Italian maiolica wares. For opaque white glazed pottery, the amount of alkalis is typically between 0.3 and 12.9 wt $\%$, but for Persian haft-rang tiles, it is significantly higher between 6.5 and $21.4 \mathrm{wt} \%$, which is directly comparable to those of white glass discussed above in "Archaeological glass data" (see also, Fig. 2).

\section{Yellow glaze data}

The distribution of $\mathrm{Pb} / \mathrm{Sn}$ values for 37 samples of yellow glazed ceramics (Fig. 4) based on data presented in Table S2 demonstrates that they all fit within the group with $\mathrm{Pb} / \mathrm{Sn}$ greater than 3.5 . The yellow glazed wares contain significantly 
higher $\mathrm{Pb} / \mathrm{Sn}$ values and less alkali contents (10.4-52.8 $\mathrm{Pb} / \mathrm{Sn}$ (Fig. 1, path 2); 3.4-15.1-wt\% $\mathrm{Na}_{2} \mathrm{O}+\mathrm{K}_{2} \mathrm{O}$ ) than the Indian and Persian yellow glazed tiles (3.4-15.1 Pb/Sn (Fig. 1, path 3); 2.7-20.8-wt\% $\mathrm{Na}_{2} \mathrm{O}+\mathrm{K}_{2} \mathrm{O}$ ); that is, the yellow glazes on tiles are closer in composition to yellow glass discussed above in "Archaeological glass data" (see, Fig. 2).

\section{Primary texts}

Calx, transliterated kals in Persian and Arabic, is described in some of the medieval and late technical texts on opaque glazed ceramic glazes in the Islamic lands and Europe. Some of the texts have only given it a passing mention as an ingredient that was mixed with ground quartz (i.e. silica) to produce opaque white glazes (see e.g. Mohammad Jowhari Nayshaburi, AD 1196; Afshar and Daryagasht 2004, 362). Others provided recipes and more detailed descriptions for calcination of lead with tin.

\section{Abu'l Qasim Kashani, 1301 AD}

One of the earliest texts that describe the calcination process of lead with tin is the Persian treatise by Abu'l Qasim Kashani (1301 AD). In the appendix to his treatise The virtues of jewels and the delicacies of perfumes (Arayis al-Jawahir va Nafayis al-Atayib), Kashani recorded recipes for lead-tin calx for opaque white glazes, with $\mathrm{Pb} / \mathrm{Sn}$ equal to 9 or 3 , or for better mixtures, 6 . The calx with $\mathrm{Pb} / \mathrm{Sn}$ equal to 3 would have been used directly in the glazing mixture (Fig. 1, path 1; " $\mathrm{Pb} / \mathrm{Sn}$ less than 3.5 "), and those with $\mathrm{Pb} / \mathrm{Sn}$ between 6 and 9 would have been used by the lead-tin alkali frit method to produce opaque white glazes (Fig. 1, path 4).

One takes 3 parts of good white lead (asrab) and a third of a part [or one part] of tin (rasās), or if one wants a better and finer mixture up to half (of a part) of tin. First they put the lead into the kiln for a time, and then they throw the tin in on top of it. They mix them at a high temperature until they are well melted. When (this mixture) brings up an earthy substance on its surface it is completely ready. They then make the fire smaller and seal the furnace door with mud. The earthy substance which collects on the melt is taken off with an iron shovel until in half a day it has all gradually changed to earth. The craftsmen call this asranj (Allan 1973, 113; Afshar 2006, 342-3).

A tin calx without lead was also used in turquoise glazes. The composition of the glaze was alkaline, and the presence of lead would have changed the colour to more green; hence, a leadless calx was preferable:

If one wants to use tin alone to get a glowing white colour, one uses two earthenware vessels. Tin is put into one and beaten with an iron pestle until it all becomes 
earthy and black in colour. It is cooled and sifted with a fine sieve on the end of a ladle, and put into a second vessel [which has been baked]; they leave it until the fire catches it and it rises nicely from its place. When it is cool it is a white earth and it is used for making turquoise preparations (Allan 1973, 113; Afshar 2006, 343).

\section{Cipriano M. Piccolpasso, 1557 AD}

Cipriano Piccolpasso (1557 AD) described the calcination procedures of lead with tin in his much-discussed treatise The three books of the potter's art (Li Tre Libri Dell'Arte Del Vasaio), an account of how Italian maiolica wares were produced. As expected from Fig. 3 (Medieval and Renaissance maiolica wares), Piccolpasso recorded using $\mathrm{Pb} / \mathrm{Sn}$ ratios equal to 4,6 , and 7 , which would have been used in the lead-tin alkali frit method to produce opaque white glazes (Fig. 1, path 4):

Let us come on now to calcination. Kindle a fire of dry wood and let it get so hot that the tin, when put into it, melts directly. Once melted, leave it in this state until such time as a skin is seen to form upon it, and then the skin to lift itself up somewhat and to crust over, and when the melted tin is quite covered over with those crusts, then and there it is pushed with that curved iron plate against the wall at the rear side. But ere I proceed further I would mix you the lead and the tin, for the tin never goes alone into the furnace. Do as follows, therefore, take: (A) Tin/ Lead $=1 \mathrm{lb} / 4 \mathrm{lb}$; (B) Tin $/$ Lead $=1 \mathrm{lb} / 6 \mathrm{lb}$; (C) Tin/Lead = $1 \mathrm{lb} / 7 \mathrm{lb}$. [...] Having made one of these combinations, put it in the furnace and follow the manner that has been explained to calcine it, keeping the fire always at an even heat, for if you were to increase it the whole would return again to a melted state. [...] This mixture of lead and tin is kept long enough in the fire for it to crust and for the crust to be constantly pressed with the iron on the wall, so that it all turns to ashes, and then when the ash becomes white or somewhat yellowish, it is collected into a copper cauldron which is quite clean and dry. To make the tin crust sooner, many are accustomed to throw some bits of sulphur into the furnace, which does not displease me! (Lightbrown and Caiger-Smith 1980, 59-60).

Piccolpasso then provided different recipes for glazes of different colours (i.e. green, yellow, light yellow, greenish-blue, light blue). For the base opaque white glazes (Lightbrown and Caiger-Smith 1980, 61-92), a mixture of marzacotto (sintered mixture of sand, wine lees and common salt) with lead-tin calx, and sometimes further sand was painted over a biscuit fired body. Coperta (a transparent glaze) or other types of decoration were applied over the unfired glaze and all fired together for a second time.

\section{Ali Mohammad Isfahani 1888}

The treatise On the manufacture of Modern Kashi Earthenware Tiles and Vases in Imitation of the Ancient by Ali Mohammad Isfahani (1888 AD) covers the manufacturing procedures for both opaque white and yellow glazes. In the first part, on the manufacture of underglaze decorated wares, Isfahani describes the process of producing calx for opaque white glazes with $\mathrm{Pb} /$ Sn ratio equal to 4 . The calx is subsequently mixed with quartz and alkaline frit (Fig. 1, path 4) to produce the glazing mixture. Note that in the text, alkaline frit is referred to as "refined paint" or "glass-like paint" and quartz as "stone."

Melt in the kiln one maund of lead (surb) and one quarter maund of tin ( $\mathrm{gal}$ ). But I must explain how to do this. Take an earthen vessel, on its side make two holes opposite to each other, place it in the kiln, throw in the lead and tin, stop up the mouth of the vessel, and heat the kiln so that the flame enters from the back hole of the vessel and comes out from the front hole in such a way that the fire clasps the lead and tin from above and below. Thus you keep on heating till the lead and tin melt. After melting, you decrease the fire gradually till the melted lead give forth a froth (kurk), then you remove the lid of the vessel, and remove to one side the froth, again decrease the fire, froth is again formed which you remove as before until the whole of the lead and tin has turned into froth.

You take it and bray it fine on a stone. Then take four parts of the previously mentioned refined paint [i.e. alkaline frit] and one part of this lead and tin (turned into froth and brayed), and mix them for a coating and varnish $\left(l a^{\prime} a b\right)$. Keep this kind (Isfahani 1888, 4).

In the second part of the treatise, Isfahani moves on to the so-called "seven-colours process" (haft-rang-sazi) for bricks and vases and explains preparation of glazing mixtures for opaque white glazes with $\mathrm{Pb} / \mathrm{Sn}$ ratio equal to 3 . This calx recipe is in accordance with the $\mathrm{Pb} / \mathrm{Sn}$ values of haft-rang glazed tiles as shown in Fig. 3. Similar to the opaque white glaze described before, the calx was mixed with an alkaline frit:

Bray as before, three parts of lead and one of tin, add to them six parts of that glass-like paint [i.e. alkaline frit] before mentioned, put all in a vessel of water with a little clear gum Arabic. With this paint the brick uniformly, place it in the kiln - using only half the previous degree of heat for this the 'seven-colours process'. On removing the brick from the kiln it will be found to be white - the effect of the above drug (Isfahani 1888, 9). 
Fig. 4 Box and whisker plot showing the distribution of $\mathrm{Pb} / \mathrm{Sn}$ values for opaque yellow glazes. The solid bar indicates $\mathrm{Pb} / \mathrm{Sn}$ equal to 3.5

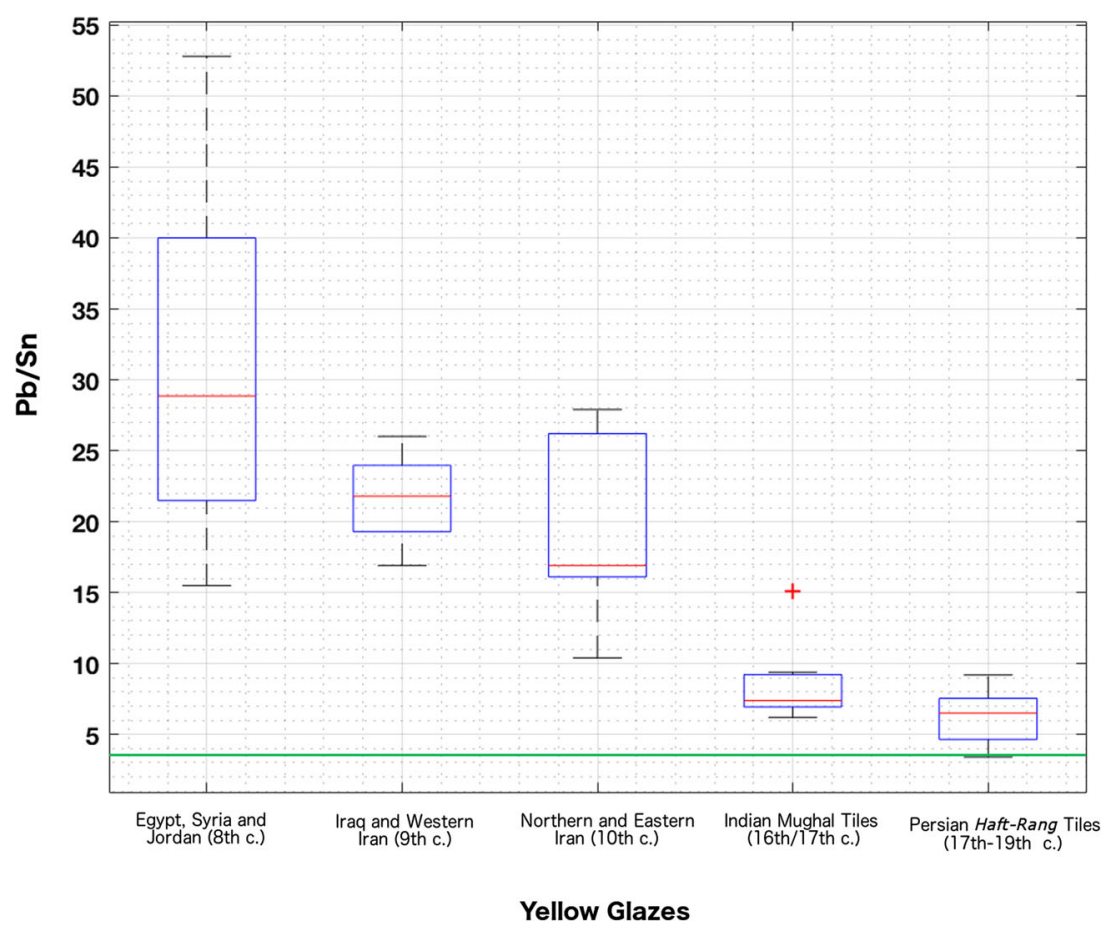

For the opaque yellow glaze, calx with $\mathrm{Pb} / \mathrm{Sn}$ equal to 16 was mixed with silica and heated (see also, Fig. 4, Persian haftrang tiles):

If you want a yellow colour, take sixteen parts of lead and one of tin, melt them together, take the froth (kurk) and heat it; when it begins to melt, add a quarter of its quantity of well brayed stone [i.e. quartz], and mix thoroughly. Bricks or vases painted with this preparation and heated, will come out of the kiln a yellow colourlike a servant who has acted perfidiously, and who, as is well known, turns yellow. With an iron ladle (sikh), skimmer-like, you must take out the yellow colour when melting, bray it, mix it with solution of gum Arabic (la'ab-i-ktira), and apply it to bricks or vases. This requires only half the heat of other colours (Isfahani 1888, 9).

\section{Traditional pottery workshops}

The city of Lalejin, located in the province of Hamedan in Central Iran, has remained the main centre of traditional pottery production in Iran after other pottery towns, such as Shahreza, Natanz, Qomsheh, Naiin, and Meibod, have almost ceased production over the last few decades. Despite the importance of the site, there seems to be no source known from either text or oral tradition on the history of the several workshops and potter families in Lalejin. In 1965, Sedigh and Karimi published a report on pottery manufacturing processes in Lalejin, Iran, based on their interview with Ustad Sadegh Azimi, then "the greatest master of pottery in Lalejin" (Sedigh and Karimi 1965, 1). As part of the preparation process of the raw materials, the master potter explains the calcination of lead with tin under "fired lead" (sorb-i pokhta). The translation of this section from Persian is as follows:

They put three manns [roughly $9 \mathrm{~kg}$ ] of lead in a pan (which is known as tavā in their local dialect) and put it in the furnace. Lead melts slowly and after it is entirely melted down, they add less than one mann [roughly $3 \mathrm{~kg}$ ] of tin, so that after melting, it is mixed with lead. On this burning mixture, something like ash emerges, which they take to a side using a stick. This gradually develops into a zarnikh [Persian name for realgar and orpiment] yellow colour. They carry on this until the whole mixture turns into the yellow powder. When mixture is very hot, they drop some tin in it to see if it sparks or not. If it does so, they say the lead is fired and they slowly pour it in a container with two wooden handles, which they call chighāvān, to cool down (Sedigh and Karimi 1965, 5).

In April 2015, the author visited Lalejin in order to study the lead-tin calcination processes that were being undertaken at several workshops there. The workshop of Mr. Seyyed Mehdi Hosseini conducted the oxidation of lead with tin for the addition to opaque glazes produced in the same workshop. The firing was carried out in an open-air furnace located at the back of the workshop. The furnace was an updraft type, 
Fig. 5 Schematic view of the furnace at Mr. Hosseini's workshop

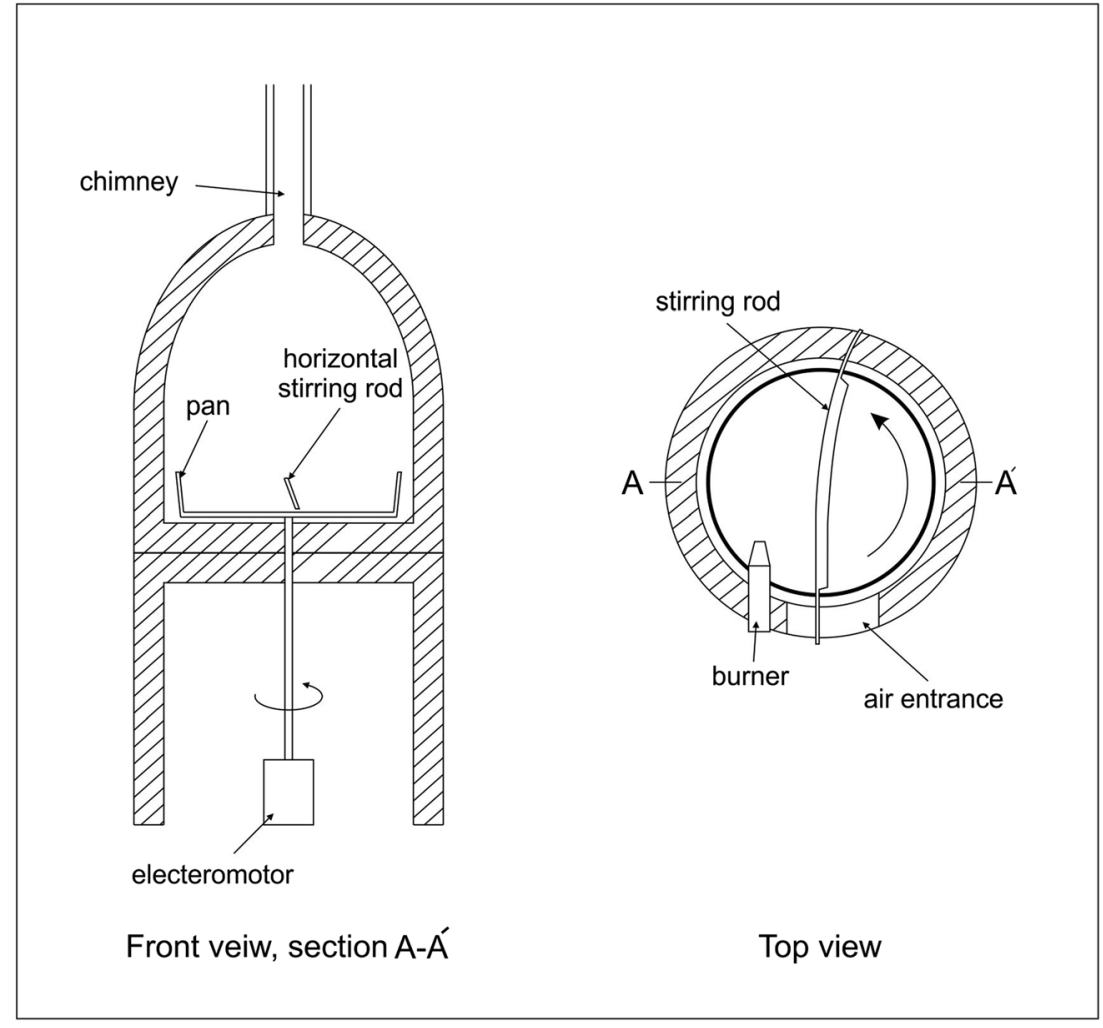

equipped with a central chimney at its roof. It comprised of a dome-shaped chamber, made of clay bricks which were covered by a fireclay paste and had an open front (Fig. 5). A stainless-steel pan was placed at the bottom of the dome. The pan was connected to an electric motor beneath the chamber and turned at a constant speed. A steel rod, approximately as long as the diameter of the pan, was set at a fixed position parallel and just above the bottom of the chamber and functioned as a constant stirrer for the mixture. A gas burner was established at the open front of the chamber. The fire was burnt red hot.

A mixture of one part of metallic tin and nine parts of metallic lead was placed in the pan and the burner was switched on. According to Mr. Hosseini:
The choice of the tin/lead ratio is a matter of finance. Higher tin:lead ratios result in enhanced opacity and general quality of the glaze. However, the potters tended to decrease the amount of tin used over the years for financial considerations.

After heating the mixture for approximately $15 \mathrm{~min}$, it started to melt and in about a further 5 min a grey earthy powder was produced (Fig. 6a). XRD analysis indicated that the powder primarily contained lead $(\mathrm{Pb})$, tin $(\mathrm{Sn})$, litharge $(\mathrm{PbO}$, tetragonal structure), massicot ( $\mathrm{PbO}$, orthotombic structure), and romarchite $(\mathrm{SnO})$, the latter being responsible for the grey colour of the powder. With another $10 \mathrm{~min}$, the mixture began to get a tint of yellow, but with the dominant colour being dark

Fig. 6 The mixture of lead with tin heated for a 20 min showing the melt mixed with grey powder and $\mathbf{b} 80 \mathrm{~min}$ showing yellow calx powder

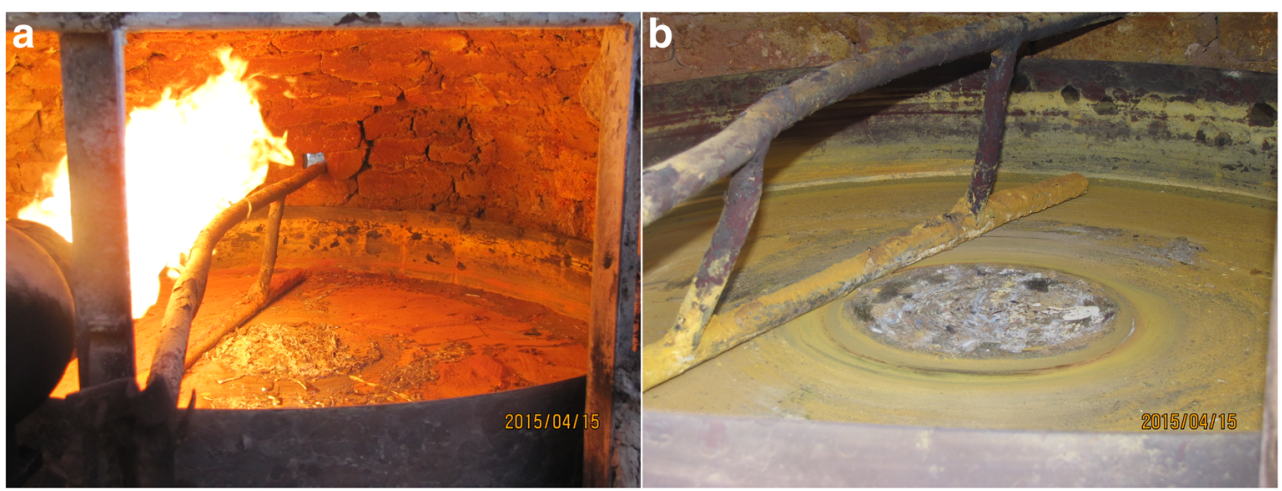


grey. The formation of yellow powder increased with time and after a further $40 \mathrm{~min}$, an entirely yellow powder was produced. This was left to cool down and was then collected for glaze production (Fig. 6b). XRD analysis of the calx powder showed mainly lead-tin-oxide in the form $\mathrm{Pb}_{2} \mathrm{SnO}_{4}$ (type I) and cassiterite $\left(\mathrm{SnO}_{2}\right)$, as well as massicot and litharge $(\mathrm{PbO})$.

\section{Conclusion and future perspectives}

Insights into the processes of tin-based opacification suggest that the calx was the main ingredient in manufacturing opaque yellow and white glass and glazes. The similarities in the compositions and the $\mathrm{Pb} / \mathrm{Sn}$ values, first, between opaque yellow glasses and glazes from eighth century Egypt and the Levant, and second, between opaque white glasses and glazes from ninth century Mesopotamia suggests that tin-based opacification of ceramic glazes is likely to have began in relationship to the development of tin-opacified glass in these regions.

For each category of opaque glass or glazed ceramics, $\mathrm{Pb} /$ Sn values can be a useful proxy for monitoring variations in the methods of opacification. Taking Rice's $(2015,202)$ description of standardised production as one in which "little heterogeneity in composition and appearance (form and style) is evident within each category," one is entitled to argue that less variations in the ranges of $\mathrm{Pb} / \mathrm{Sn}$ of calces may suggest a more standardised production for opaque glass and glazes. For instance, the $\mathrm{Pb} / \mathrm{Sn}$ values for Persian Mina'i and lustre wares, considered to have been produced in Kashan, fall within a very tight range between 2.5 and 3.3 with the median of 3 for Mina'i wares, and between 5.4 and 7.6 with the median of 7.2 for lustre wares. This is in agreement with Abu'l Qasim Kashani's recipe for calx with $\mathrm{Pb} / \mathrm{Sn}$ of 3, 6, and 9 for opaque white glazes. Similarly, the $\mathrm{Pb} / \mathrm{Sn}$ values for Italian maiolica wares and Persian haft-rang tiles fit within a relatively tight range and are in agreement with recipes given by Piccolpasso for maiolica wares with $\mathrm{Pb} / \mathrm{Sn}$ values of 4,6 , and 7 and by Isfahani for haft-rang tiles with $\mathrm{Pb} / \mathrm{Sn}$ value of 3 . For opaque yellow glazes of haft-rang tiles, the $\mathrm{Pb} / \mathrm{Sn}$ values range between 3.4 and 15.1 with the median of 7, but they are far from the $\mathrm{Pb} / \mathrm{Sn}$ value of 16 that is suggested in the recipe by Isfahani.

The widest ranges of variations in $\mathrm{Pb} / \mathrm{Sn}$ values for opaque white glazes are seen in Egyptian lustre and Iznik wares; for opaque yellow glazes, in Egyptian and Levantine wares; and for glasses, in red, green, and yellow glasses. In general, the extent of variations of $\mathrm{Pb} / \mathrm{Sn}$ values in opaque yellow glass and glazes is more than that in opaque white glass and glazes. This is partly due to the fact that, in opaque yellow glasses and glazes, the $\mathrm{Pb} / \mathrm{Sn}$ values in the calx must be above 3.5 as dictated by the stoichiometric ratios, but there is no maximum limit for the $\mathrm{Pb} / \mathrm{Sn}$ ratio from which yellow opacity results. Therefore, $\mathrm{PbO}$ concentrations as high as nearly $70 \mathrm{wt} \%$ were used in yellow glasses and glazes. In the yellow pottery glazes, lead oxide also acted as the main fluxing agent since the amounts of alkalis in the composition of these glazes is negligible.

This paper will hopefully encourage further studies of the composition and production procedures of lead-tin calces by examining different types of opaque glass and ceramic glazes.

Acknowledgements I am grateful to Professor Michael Tite and two anonymous referees for their valuable comments on an earlier draft of this paper.

Open Access This article is distributed under the terms of the Creative Commons Attribution 4.0 International License (http:// creativecommons.org/licenses/by/4.0/), which permits unrestricted use, distribution, and reproduction in any medium, provided you give appropriate credit to the original author(s) and the source, provide a link to the Creative Commons license, and indicate if changes were made.

Publisher's Note Springer Nature remains neutral with regard to jurisdictional claims in published maps and institutional affiliations.

\section{References}

Afshar I (2006) Arāyes al-Jawāher va Nafāyes al-Atāyeb, Abu'l-Qāsim A. Kāshānī. Entesharat-i al-Maie, Tehran [Persian]

Afshar I, Daryagasht MR (2004) Jawāhirnāma-yi Nizāmī, Mohammad B. A.B. Jowhari Nayshaburi, Tehran: Miras-i Maktub Press [Persian]

Allan JW (1973) Abu'l-Qasim's treatise on ceramics, IRAN, 11:111-120

Arletti R, Conte S, Vandini M, Fiori C, Bracci S, Bacci M, Porcinai S (2011a) Florence baptistery: chemical and mineralogical investigation of glass mosaic tesserae. J Archaeol Sci 38(1):79-88

Arletti R, Vezzalini G, Fiori C, Vandini M (2011b) Mosaic glass from St Peter's, Rome: manufacturing techniques and raw materials employed in late 16th-century Italian opaque glass. Archaeometry 53(2):364-386

Arnon YD (2008) Caesarea Maritima, the late periods (700-1291 CE), BAR International Series 1771. Archaeopress, Oxford

Avissar M (1996) The medieval pottery. In: Ben-Tor A, Avissar M, Portugali Y (eds) Yokne'am I, the late period, Qedem Reports, 3. The Institute of Archaeology, The Hebrew University of Jerusalem, Jerusalem, pp 75-262

Bagci Y (2016) Colours of the caliphs, shades of the Thughur al Sham: revisiting early Islamic ceramics from 1935-1948 Gozlukule excavations in Tarsus (Southern Turkey), unpublished $\mathrm{PhD}$ thesis, Leiden: University of Leiden

Bayley J (1981) The analysis of a yellow bead from Jutland, Ancient Monuments Laboratory (AML) Report Series, No. 3457, Historic England

Bayley J (2000) Glassworking in early medieval England, In: Price J (ed) Glass in Britain and Ireland AD 350-1100. British Museum Occasional Paper No. 127, pp 137-142

Bayley J, Wilthew P (1986) Qualitative and semiquantitative analyses of glass beads. In: Olin JS, Blackman MJ (eds) Proceedings of the 24th International Archaeometry Symposium. Smithsonian Institution Press, Washington DC, pp 55-62

Biek L, Kay PJ (1982) Evidence of glass melting, In: Leech R (ed) Excavations at Catsgore 1970-1973, a Romano-British village, western archaeological trust, Excavation monograph no. 2, p 132133 
Bloemers JHF, Kooijmans LP, Sarafatij H (1986) Verleden land: archeologische opgravingen in Nederland, Amsterdam, 132

Bonnerot O, Ceglia A, Michaelides D (2016) Technology and materials of Early Christian Cypriot wall mosaics. J Archaeol Sci Rep 7:649-661

Brill RH (1999) Chemical analyses of early glasses. Canfield and Tack, Rochester, pp 527-544

Brill RH, Whitehouse D (1988) The Thomas panel. J Glass Stud 30:34-50

Caiger-Smith A (1973) Tin-glaze pottery in Europe and the Islamic world: the tradition of 1000 years in maiolica, faience and delftware. Faber, London

Clark R, Cridland L, Kariuki B, Harris K, Withnall R (1995) Synthesis, structural characterisation and Raman spectroscopy of the inorganics pigments lead tin yellow types I and II and lead antimony yellow: their identification on medieval paintings and manuscripts. J Chem Soc Dalton Trans (16):2577-2582

Engeman J (1990) Early Islamic glazed pottery of the eight century AD from the excavations at Abu Mina. In: Godlewski W (ed) Coptic and Nubian pottery, part I: international workshop, Nieborów, August 29-31, 1988. National Museum in Warsaw, Warsaw, pp 63-70

Fiorentino S, Vandini M, Chinni T, Caccia M, Martini M, Galli A (2017) Colourants and opacifiers of mosaic glass tesserae from Khirbet alMafjar (Jericho, Palestine): addressing technological issues by a multi-analytical approachand evaluating the potentialities of thermoluminescence and optically stimulated luminescence dating. J Archaeol Anthropol Sci:1-23

Fiorentino S, Chinni T, Cirelli E, Arletti R, Conte S, Vandini M (2018) Considering the effects of the Byzantine-Islamic transition: Umayyad glass tesserae and vessels from the qasr of Khirbet alMafjar (Jericho, Palestine). J Archaeol Anthropol Sci 10:223-245

Fourest HP (1980) Delftware: faience production at Delft, translated by K. Watson, London: Thames and Hudson

Freestone IC, Bimson M, Buckton D (1990) Compositional categories of Byzantine glass tesserae, Annales du 11e Congrès de l'Association Internationale pour l'Histoire du Verre e (Bale 1998), p 271-9

Gayraud RP (2009) Assemblages de ceramiques egyptiennes dates pae les fouilles d'Istabl Antar (milieu VIIe-2ere moitie du Xe s.), In: Zozaya J, et al (eds) Actas del VIII Congreso Internacional de Cerámica Medieval en el Mediterráneo: Ciudad Real-Almagro, del 27 de febrero al 3 de marzo de 2006, 1, Asociación Española de Arqueología Medieval, p 171-192

Gill MS, Rehren T, Freestone I (2014) Tradition and indigeneity in Mughal architectural glazed tiles. J Archaeol Sci 49:546-555

Heck M, Rehren T, Hoffmann P (2003) The production of lead-tin yellow at Merovingian Schleitheim (Switzerland). Archaeometry 45(1):33-44

Henderson J (1988) Electron-microprobe investigation of early Irish glass and glassmaking practices. In: Sayre EW, Vandiver PB, Druzik J, Stevenson C (eds) Materials Research Society Symposium Proceedings 123. Materials issues in art and archaeology. Materials Research Society, pp 141-146

Henderson J (1989) Iznik ceramics: a technical examination. In: Atasoy N, Raby J (eds) Iznik - the pottery of Ottoman, Turkey, 65-9. Alexandria Press, London, pp 84-87

Henderson J (1990) The scientific investigation of the glass beads from the Apple Down Anglo-Saxon Cemetry, In: Down A, Welch M (eds) Apple Down and the Mardens, Chichester excavations 7, Chichester District Council, p 156-164

Henderson J (1999) Scientific analysis of the glass and the glass-bearing artefacts: technique, raw materials used and archaeological interpretation, In: Besteman J, Bos J, Gerrets D, Heidinga HA (eds) The excavation near Wijnaldum. Reports on Frisia in Roman and Medieval Times, vol. 1, p 287-298

Henderson J, Warren SE (1983) Analysis of prehistoric lead glass. In: Aspinall A, Warren SE (eds) Proceedings of the 22nd Symposium on Archaeometry. University of Bradford, Bradford, pp 168-180

Holakooei P, Tisato F, Vaccaro C, Petrucci FC (2014) Haft rang or cuerda seca? Spectroscopic approaches to the study of overglaze polychrome tiles from seventeenth century Persian. J Archaeol Sci $41: 447-460$

Isfahani AM (1888) On the manufacture of modern Kashi earthenware tiles and vases, In: Imitation of the ancient, museum of science and art, Edinburgh

Joel G (1992) Céramique glacurées d'époque Islamique trouvées à Tod, Annales Islamologiques, 26. Institute Francais d'Archéologie Orientale du Caire (IFAO), Cairo, pp 1-18

Kühn H (1968) Lead-tin yellow. Stud Conserv 13(1):7-33

Lightbown RW, Caiger-Smith A (1980) The three books of the potter's art, by Cipriano Piccolpasso. Scolar Press, London

Maltoni S, Silvestri A (2018) Innovation and tradition in the fourth century mosaic of the Casa delle Bestie Ferite in Aquileia, Italy: archaeometric characterisation of the glass tesserae. Archaeol Anthropol Sci 10(2):415-429

Marii F (2013) Glass tesserae from the Petra Church. In: Entwistle C, James L (eds) New light on old glass: recent research on Byzantine mosaics and glass. British Museum, London, pp 11-24

Mason RB, Tite MS (1997) The beginnings of tin opacification of pottery glazes. Archaeometry 39(1):41-58

Mason RB, Tite MS, Paynter S, Salter C (2001) Advances in polychrome ceramics in the Islamic world of the 12 th century AD. Archaeometry 43(2):191-209

Matin M, Tite M, Watson O (2018) On the origins of tin-opacified ceramic glazes: new evidence from early Islamic Egypt, the Levant, Mesopotamia, Iran, and Central Asia. J Archaeol Sci 97:42-66

Matin, M, Nemati (forthcoming) Nineteenth-century Persian tiles from the Ettehadieh House: an investigation of the composition and microstructure

Molera J, Pradell T, Salvadó N, Vendrell-Saz M (1999) Evidence of tin oxide recrystallization in opacified lead glazes. J Am Ceram Soc 82(10):2871-2875

Molera J, Vendrell Saz M, Pérez-Arantegui J (2001) Chemical and textural characterization of tin glazes in Islamic ceramics from eastern Spain. J Archaeol Sci 28(3):331-340

Molina G, Tite MS, Molera J, Climent-Font A, Pradell T (2014) Technology of production of polychrome lustre. J Eur Ceram Soc 34:2563-2574

Moretti C, Hreglich S (1984) Opacification and coloring of glass by the use of anime. Glass Technol 25:277-282

Neri E, Verita M, Conventi A (2013) Glass mosaic tesserae from the $5^{\text {th }}$ to $6^{\text {th }}$ century Bapistery of San Giovanni alle Fonti Milan, Italy: analytical investigation. In: Entwistle C, James L (eds) New light on old glass: recent research on Byzantine mosaics and glass. British Museum, London, pp 1-10

Neri E, Jackson M, O’Hea M, Gregory T, Blet-Lemarquand S (2017) Analyses of glass tesserae from Kilise Tepe: new insights into an early Byzantine production technology. J Archaeol Sci Rep 11:600-612

Okyar F (2002) Characterisation of Iznik ceramics. In: Archaeometry 98, Jerem E, Biro KT (eds) BAR International Series 1043 (II), Oxford: Archaeopress, pp 621-6

Paynter S, Okyar F, Wolf S, Tite MS (2004) The production technology of Iznik pottery - a reassessment. Archaeometry 46(3):421-437

Peake JRN, Freestone IC (2014) Opaque yellow glass production in the early medieval period: new evidence. In: Keller D, Price J, Jackson C (eds) Neighbours and successors of Rome: traditions of glass production and use in Europe and the Middle East in the later $1^{\text {st }}$ millennium AD. Oxbow Books, Oxford, pp 15-21

Pilosi L, Stamm K, Wypyski MT (2012) An Islamic cameo glass fragment in the Metropolitan Museum of Art. In: Annales du 18e Congrès de l'Association Internationale pour l'Histoire du Verre (Thessaloniki 2009), pp 341-345

Pradell T, Molera J, Smith AD, Tite MS (2008) Early Islamic lustre from Egypt, Syria and Iran (10th to 13th century AD). J Archaeol Sci 35: 2649-2662 
Rice PM (2015) Pottery analysis: a sourcebook, Chicago. University of Chicago Press, London

Rooksby HP (1962) Opacifiers in opal glasses through the ages. GEC J Sci Technol 29:20-26

Rooksby HP (1964) A yellow cubic lead tin oxide opacifier in ancient glasses. Phys Chem Glasses 5:20-25

Sablerrolles Y (1999) Beads of glass, faience, amber, baked clay and metal, including production waste from glass and amber bead making. In: Besteman J, Bos J, Gerrets D, Heidinga HA (eds) The excavation near Wijnaldum, Reports on Frisia in Roman and Medieval times, vol 1, pp 253-286

Sablerrolles Y, Henderson J, Dijkman W (1997) Early medieval glass bead making in Maastricht (Jodenstraat 30), The Netherlands. An archaeological and scientific investigation, In: Frreden U, Wieczorek A (eds) Perlen, Archäologie, Techniken, Analysen; Akten des Internationalen Perlensymposiums in Mannheim vom 11. bis 14. November 1994. R. Habelt, Bonn

Scanlon GT (1998) Slip-painted early lead-glazed wares from Fustat: a dilemma of nomenclature. In: Gayraud RP (ed) Colloque International d'Archéologie Islamique 3-7 février 1993. Institute Francais d'Archéologie Orientale du Caire (IFAO), Cairo, pp 21-53

Schibille N, McKenzie J (2014) Glass tesserae from Hagios Polyeuktos, Constantinople: their early Byzantine affiliations. In: Keller D, Price J, Jackson C (eds) Neighbours and successors of Rome: traditions of glass production and use in Europe and the Middle East in the later $1^{\text {st }}$ millennium AD. Oxbow Books, Oxford, pp 114-127

Schibille N, Degryse P, Corremans M, Specht C (2012) Chemical characterisation of glass mosaic tesserae from sixth-century Sagalassos (south-west Turkey): chronology and production techniques. J Archaeol Sci 39:1480-1492

Schibille N, Neri E, Ebanista C, Ramzi Ammar M, Bisconti F (2018a) Something old, something new: the late antique mosaics from the catacomb of San Gennaro (Naples). J Archaeol Sci Rep 20:411-422

Schibille N, Meek A, Wypyski MT, Kröger J, Rosser-Owen M, Wade Haddon R (2018b) The glass walls of Samarra (Iraq): ninth-century Abbasid glass production and imports. PLoS One 13:e0201749

Sedigh M, Karimi A (1965) Sofālgarī dar Lālejīn (Pottery making in Lālejīn). Honar va Mardom 3(30):1-7 [Persian]

Silvestri A, Tonietto S, Molin G, Guerriero P (2014) The Palaeo-Christian glass mosaic of St. Prosdocimus (Padova, Italy): archaeometric characterisation of tesserae with copper- or tin-based opacifiers. J Archaeol Sci 42:51-67

Stacey DA (1995) The archaeology of early Islamic Tiberias, unpublished $\mathrm{PhD}$ thesis, London: University of London

Tite MS (1989) Iznik pottery: an investigation of the methods of production. Archaeometry 31:115-132

Tite MS (2009) The production technology of Italian maiolica: a reassessment. J Archaeol Sci 36:2065-2080

Tite MS, Pradell T, Shortland A (2008) Discovery, production and use of tin-based opacifiers in glasses, enamels and glazes from the Late Iron Age onwards: a reassessment. Archaeometry 50(1):67-84
Tite MS, Watson O, Pradell T, Matin M, Molina G, Domoney K, Bouquillon A (2015) Revisiting the beginnings of tin-opacified Islamic glazes. J Archaeol Sci 57:80-91

Tite MS, Shortland A, Schibille N, Degryse P (2016) New data on the soda flux used in the production of Iznik glazes and Byzantine glasses. Archaeometry 58(1):57-67

Turner WES, Rooksby HP (1961) Further historical studies based on Xray diffraction methods of the reagents employed in making opal and opaque glasses. Jahrbuch des Römisch-Germanischen Zentralmuseum 8:1-6

Uboldi M, Verità M (2003) Scientific analyses of glasses from late antique and early medieval archaeological sites in northern Italy. Journal of Glass Studies 45:115-137

Vandini M, Arletti R, Cirelli E (2014) Five centuries of mosaic glass at Saint Severus (Classe, Ravenna). OCNUS 22:91-108

Verità M, Santopadre P, De Palma G (2017) Scientific investigation of glass mosaic tesserae from the 8th century AD archaeological site of Qusayr' Amra (Jordan). Boll ICR 32:7-18

Vorderstrasse T (2005) Al-Mina: a port of Antioch from Late Antiquity to the End of the Ottomans. Instituut voor het Nabije Oosten, Nederlands

Waage FO (1948) Antioch-on-the-Orontes IV, part one: ceramics and Islamic coins. Princeton University Press, Princeton

Walmsley AG (1995) Tradition, innovation and imitation in the material culture of Islamic Jordan: the first four centuries, In: Hadid A (ed) Studies in the history and archaeology of Jordan, 5, Amman, p 657 668

Walmsley AG (1997) Ceramics and the social history of Early Islamic Jordan: the example of Pella (Tabaqat Fahl), Al-'Usur Al-Wusta, The Bulletin of Middle East Medievalists, 9, 1-3 and 12

Watson O (1999) VIII. Report on the glazed ceramics, In: Miglus PA (ed) Ar-Raqqa I: Die Frühislamische Keramik von Tell Aswad, Mainz, 81-87, Taf., p 94-99

Werner AE, Bimson M (1967) Technical report on the glass gaming pieces. In: Stead IM (ed) A La Tène III burial at Welwyn Garden City. Archaeologia, p 101, 1-62

Whitcomb D (1989) Glazed ceramics from the excavations at Aqaba, Jordan. J Am Res Centre Egypt 26:167-182

Whitcomb D (1991) Glazed ceramics of the Abbasid period from the Aqaba excavations, Transactions of the Oriental Ceramic Society (1990-91), 55:43-65

Whitcomb D (1999) Hadir Qinnasrin, The Oriental Institute of the University of Chicago,1998-1999 Annual Report, p 76-83

Wood N, Tite MS, Doherty C, Gilmore B (2007) A technological examination of ninth-tenth century AD Abbasid blue-and-white ware from Iraq, and its comparison with eight century $\mathrm{AD}$ Chinese blue-and-white Sancai ware. Archaeometry 49(4):665-684

Wypyski MT (2005) Technical analysis of glass mosaic tesserae from Amorium. DOP 59:183-192

Wypyski M (2015) Chemical analysis of early Islamic glass from Nishapur. J Glass Stud 57:121-136 